\title{
PHEROMONE BIOSYNTHESIS IN THE BARK BEETLE, IPS PARACONFUSUS, DURING FEEDING OR EXPOSURE TO VAPOURS OF HOST PLANT PRECURSORS
}

\author{
J. A. BYERS \\ Department of Entomological Sciences, University of California at Berkeley, Berkeley, CA 94720, \\ U.S.A.
}

(Received 7 January 1981)

\begin{abstract}
The quantities of trans-verbenol, myrtenol, and the pheromone, cis-verbenol, in the hindguts of males and females were found to increase in linear proportion following exposure to increasing concentrations of vapour of the host plant precursor, $(-)$ - $\alpha$-pinene. Males produced significantly more of these compounds than females. Differences between males and females in the ratios of compound production were indicated.

The concentrations of myrcene, $\alpha$-pinene, and other monoterpenes volatilized in male nuptial chambers in ponderosa pine were quantified as well as the amounts in phloem. Males do not appear to ingest sufficient phloem to obtain enough of the host plant precursor, myrcene, to account for production of the pheromones, ipsenol and ipsdienol, but they may consume additional amounts of myrcene in oleoresin/xylem. Comparisons of ipsenol, ipsdienol and cis-verbenol production in males when feeding or exposed to precursor vapours at various concentrations indicate that under natural conditions myrcene used in pheromone biosynthesis primarily enters the beetle via the digestive tract.

Key Word Index: Ips paraconfusus, Pinus ponderosa, pheromone biosynthesis, bark beetle, myrcene, $\alpha$-pinene, monoterpenes, ipsenol, ipsdienol, cis-verbenol, trans-verbenol, myrtenol, attractants, pheromones.
\end{abstract}

\section{INTRODUCTION}

BoTH sexes of the bark beetle Ips paraconfusus (Lanier) are attracted to the pheromone mixture, ipsenol, cisverbenol and ipsdienol, produced by males feeding in ponderosa pine (SILVERSTEIN et al., 1966a, b; WoOD et al., 1968). Only male $I$. paraconfusus produce ipsenol and ipsdienol when exposed to vapours of the host plant monoterpene, myrcene (HuGHES, 1974; BYERS et al., 1979). HENDRY et al. (1980) showed that $\mathrm{D}_{2}$-labelled myrcene was directly converted to these pheromones. The relationship between the concentration of myrcene in vapour phase and subsequent ipsenol and ipsdienol production was quantified by BYERS et al. (1979). Bacillus cereus isolated from the hindgut of $I$. paraconfusus converted racemic $\alpha$-pinene to cis-verbenol and trans-verbenol in vitro (BRAND et al., 1975). RENWICK et al. (1976a) using NMR, IR and GC-MS methods reported that both sexes produced cis-verbenol when exposed to the vapour of $(-)-\alpha$-pinene and produced trans-verbenol when exposed to the $(t)$ enantiomer. However, the relationship between the concentration of the suspected pheromone precursor, (-)- $\alpha$-pinene, and the production of cis-verbenol in each sex has not been established.

In the above studies where beetles were exposed to vapours of $\alpha$-pinene and myrcene, there have been no attempts to determine whether the concentrations tested were similar to that which beetles encounter in nature. Therefore, the relative roles of feeding and vapour exposure (absorption/breathing) in the acquisition of precursors by the beetle during host colonization is not known. Furthermore, the source of pheromone precursors in host tissue is not well characterized. The beetle appears to feed primarily on phloem, but the concentrations of monoterpenes in this tissue have not been investigated. The presence of $\alpha$-pinene, myrcene and other monoterpenes in pine xylem has been determined by Mirov (1961) but the quantities are not precisely known. Knowledge of the quantities of other major monoterpenes is important since they affect the vapour pressures of the known precursors, they may be potential pheromone precursors, and they have been implicated as toxicants in host resistance (SMITH, 1966b). Therefore, the objectives of this study were to: (1) quantify the relationship between the concentration of $\alpha$-pinene in the vapour phase and subsequent pheromone production, (2) determine the concentration of the pheromone precursors (myrcene and $\alpha$-pinene) and other major monoterpenes in the headspace of male nuptial chambers and in the phloem and (3) determine the major route of entry of pheromone precursors into beetles in nature.

\section{MATERIALS AND METHODS}

Relationship between concentration of $\alpha$-pinene vapour and cisverbenol, trans-verbenol and myrtenol production in I. paraconfusus

Ips paraconfusus adults were reared (BROWNE, 1972) from naturally infested ponderosa pine logging debris obtained from the Sierra National Forest, California, at about $1000 \mathrm{~m}$ elevation. The adults were stored on moistened paper at $4^{\circ} \mathrm{C}$ 


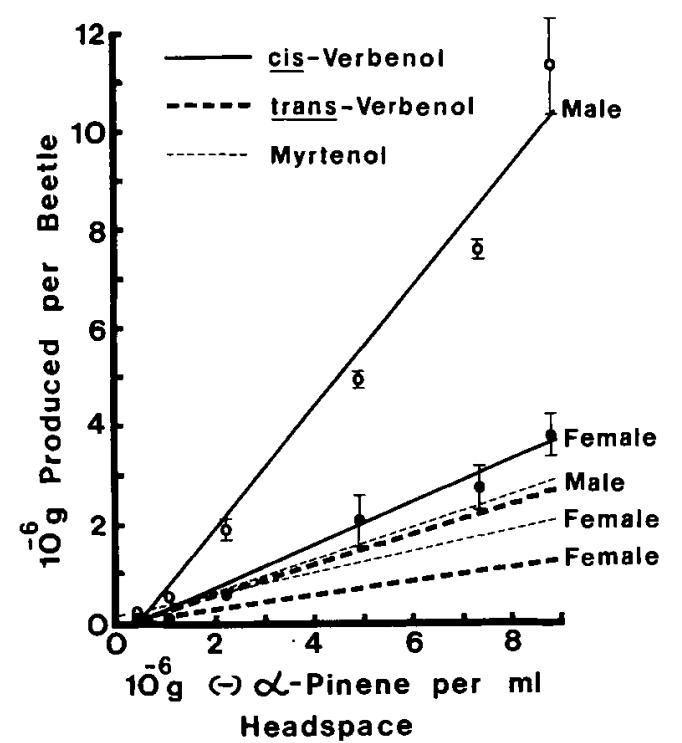

Fig. 1. Cis-verbenol, trans-verbenol and myrtenol production in male Ips paraconfusus after exposure to $(-)-\alpha$-pinene vapours. Brackets \pm S.E.M. $n=2$.

from 2 to 15 days before use. Male and female beetles were exposed to various concentrations of $(-)-\alpha$-pinene vapour $\left([\alpha]_{\mathbb{D}}^{22}=-41.6^{\circ}\right.$, GLC purified $>99.8 \%$ Aldrich $)$ for $18 \pm 0.5$ hr at $21 \pm 1.7^{\circ} \mathrm{C}$ under natural light. Two groups of 15 of each sex were exposed separately to vapours in bottles containing $0.2,1,3,6,12,20,30,80$ and $160 \mu \mathrm{l}$ of $(-)-\alpha$-pinene (BYERS et al., 1979). Samples of headspace air were withdrawn from the bottles during the exposure period and the concentration of $\alpha$-pinene vapour was determined by GLC analysis using a $3.7 \mathrm{~m} \times 2 \mathrm{~mm}$ i.d. glass column of Ultrabond II (monolayer Carbowax 20M, 100/120 mesh) at $50^{\circ} \mathrm{C}$ and $\mathrm{N}_{2}$ flow of 30 $\mathrm{ml} / \mathrm{min}$.

After the exposure period, the posterior portion of the beetles' guts, including the mid-and hind-guts, were removed and immediately crushed in $0.3 \mathrm{ml}$ of diethyl ether. The gut extracts were analysed on Ultrabond II at $100^{\circ} \mathrm{C}$. The quantities of $c$ is-verbenol, trans-verbenol and myrtenol were determined by comparison of GLC peak areas with known amounts of these compounds (GLC purified $>99 \%$, Chemical Samples Co. and Aldrich). Mortality was recorded after the vapour exposure and only living beetles were extracted for compounds. Linear regression and analysis of covariance (SNEDECOR and COCHRAN, 1967) were performed on the quantities of compounds in each sex (Fig. 1) to determine if quantitative differences in production existed between males and females. Similar comparisons were made between regression lines of ratios of compounds produced by males (e.g. cis-verbenol compared with trans-verbenol) and corresponding lines for compounds produced by females.

Concentration of myrcene, $\alpha$-pinene, and other monoterpenes in ponderosa pine phloem and in the headspace of male nuptial chambers

Males were allowed to bore and construct nuptial chambers in a $12 \mathrm{~cm}$ dia. $\times 25 \mathrm{~cm}$ long ponderosa pine log (17 March 1976). The average volume of 14 nuptial chambers after $48 \mathrm{hr}$ of boring $(111.3 \pm 7.3 \mu \mathrm{l}, \pm$ S.E.M.) was determined by filling chambers with glycerol. The head-space air from 8 to 16 nuptial chambers was sampled for monoterpenes on each date (see Fig. 2). The needle of a gastight syringe (Hamilton) was fitted with a $1.5 \mathrm{~cm}$ length of Teflon 14 GA 'spaghetti' tubing ( 1 mm o.d.) which was gently inserted about $1.5 \mathrm{~cm}$ into the nuptial chamber until the opposite end was encountered. Fifteen microlitres (about

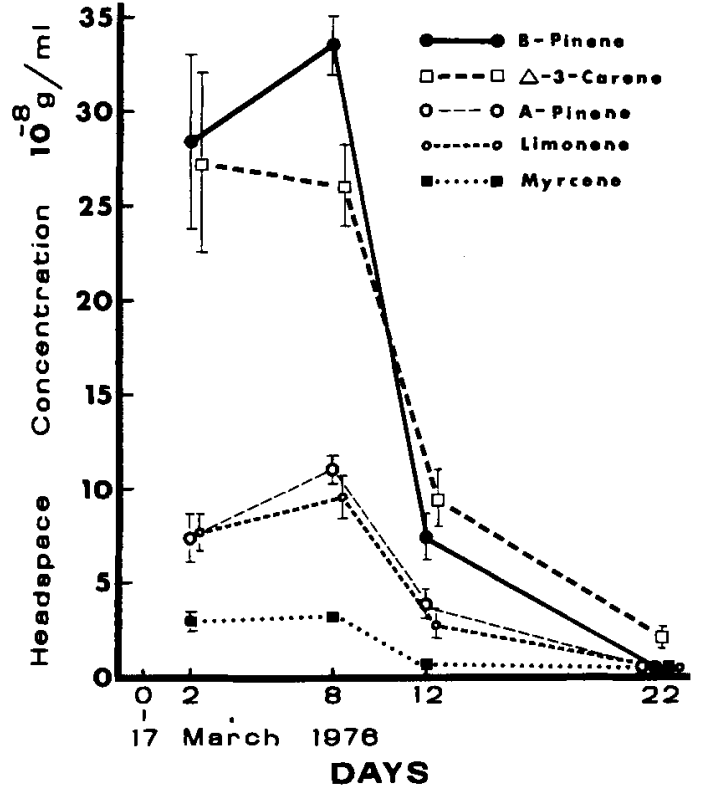

Fig. 2. Concentration of monoterpene vapours in the headspace of male $I$. paraconfusus nuptial chambers during a 22-day period of boring in a ponderosa pine log. Brackets

$$
\pm \text { S.E.M. } n=4 \text {. }
$$

$13.5 \%$ of the nuptial chamber volume) was withdrawn from each of four chambers, for a total sample size of $60 \mu$ l. The tube then was removed and the sample injected into a 1.8 $\mathrm{m} \times 2 \mathrm{~mm}$ i.d. GLC glass column of $10 \%(\mathrm{w} / \mathrm{w})$ FFAP on $80 / 100 \mathrm{Gas}$ Chrom $Q$ at $50^{\circ} \mathrm{C}$ and $\mathrm{N}_{2}$ flow of $30 \mathrm{ml} / \mathrm{min}$. The same procedure was used to sample nuptial chambers in logs (14 cm dia.) from three additional trees (Table 3 ) with GLC analyses performed with the Ultrabond II column at $50^{\circ} \mathrm{C}$ (Feb. 18-19 1978) and a $1.8 \mathrm{~m} \times 2 \mathrm{~mm}$ i.d. glass column of $3 \%$ (w/w) Apiezon $\mathrm{L}$ on $100 / 120 \mathrm{Gas}$ Chrom $\mathrm{Q}$ at $100^{\circ} \mathrm{C}$ and $\mathrm{N}_{2}$ flow of $12 \mathrm{ml} / \mathrm{min}$ (15 November 1977). The quantities of $\alpha$ pinene, myrcene, $\beta$-pinene, $\Delta$-3-carene, and limonene present in the headspace samples were measured by comparing peak areas and retention times with known amounts of these compounds (GLC purified > 98\%, Chemical Samples Co. and Aldrich) on the three columns described above.

Phloem tissue was removed on 17 May 1976, from each of three ponderosa pine logs obtained from two trees cut on 4 May (tree No. 1) and 22 April (tree No. 2). Each sample was weighed $(0.6-1.9 \mathrm{~g})$ and then ground in diethyl ether in a mortar and pestle for $3 \mathrm{~min}$. Ether was added during the trituration period to compensate for evaporation so that about $2 \mathrm{ml}$ of extract could be removed from the pulp. A second and third extraction were performed similarly and the quantities of each monoterpene in the extracts were analysed by GLC on the Apiezon L column described earlier. Exponential regression of the monoterpene amounts in each extraction step was used to determine the efficiency of the extraction process and to estimate the amounts that may have remained in the ground phloem.

Pheromone production in I. paraconfusus males after feeding in ponderosa pine and after exposure to vapours of myrcene and $(-)-\alpha-p$ inene in the laboratory

Ponderosa pine logs about $14 \mathrm{~cm} \mathrm{dia.} \times 28 \mathrm{~cm}$ long were cut from trees and stored less than 1.5 months at $4^{\circ} \mathrm{C}$ before use. Males were introduced head-first into holes drilled in logs (BYERS and WOOD, 1980) and allowed to excavate nuptial chambers for $48 \pm 1 \mathrm{hr}$ under natural light on each of four dates (30 April 1976, 30 June 1976, 18 February 1978 and 8 September 1978). Females were introduced similarly in other logs on 30 April and 30 June 1976. Eleven groups of 
15-40 males were removed from the logs (2-3 groups per log) and extracted for the presence of pheromones in their guts as described earlier. Two groups of 20-40 females were treated the same way. The amounts of pheromones present in the male and female guts were determined by GLC analysis on the above Ultrabond II, Apiezon L and FFAP columns at $100^{\circ} \mathrm{C}$.

Three groups of 20 males were exposed to vapours of myrcene $\left(21 \pm 3 \times 10^{-7} \mathrm{~g} / \mathrm{ml}\right)$ and $(-)-\alpha$-pinene $\left(54 \pm 4 \times 10^{-7} \mathrm{~g} / \mathrm{ml}\right)$ in the bottles for $48 \pm 0.5 \mathrm{hr}$ on 10 May 1980. Quantities of pheromones in their guts were determined as described.

\section{RESULTS}

Relationship between concentration of $\alpha$-pinene vapour and cis-verbenol, trans-verbenol, and myrtenol production in $\mathbf{I}$. paraconfusus

The biosynthesis of cis-verbenol, trans-verbenol and myrtenol in male and female $I$. paraconfusus exposed to increasing concentrations of $\alpha$-pinene [about $89.7 \%$ $(-)$ and $10.3 \%(+)$ enantiomers] were linear over the range tested (Fig. 1). Considerably higher concentrations of $\alpha$-pinene would have been necessary to begin saturating the catalytic site(s) and determine $K_{m}$ values. Higher concentrations of $\alpha$-pinene were tested but mortality due to fumigant toxic effects (SmITH, 1965a, b) precluded valid results (Table 1). A comparison of the regression lines for each compound in male and female beetles showed that males consistently produced more of all three compounds than females (Table 2). Not only were the absolute amounts different in each sex, but the relative proportions of the three compounds differed between the sexes (Table 2).

Concentration of myrcene, $\alpha$-pinene, and other monoterpenes in ponderosa pine phloem and in the headspace of male nuptial chambers

The concentration of the major monoterpenes in the headspace of male nuptial chambers decreased precipitously after eight days and was less than $2 \times 10^{-8} \mathrm{~g} / \mathrm{ml}$ at 22 days (Fig. 2). The average concentration of myrcene vapour in the nuptial chamber after $48 \mathrm{hr}$ of excavation in several trees (Table 3) was only about $2.4 \%$ of the myrcene concentration at near saturation in a bottle (BYERS, et al., 1979). The concentration of $\alpha$-pinene vapour in a nuptial chamber also was much less concentrated than in a bottle with $30 \mu \mathrm{l} \alpha$-pinene (about $2.3 \%$, Table 1).
The amounts of monoterpenes in the phloem of two trees are shown in Table 4. Exponential regression of the extraction number against the quantities of each monoterpene showed correlation coefficients of 0.99 in all cases. This relationship would be expected if a certain percentage of the monoterpenes were removed from the tissue on each subsequent extraction. The regressions indicated that in two of the samples, the three extractions removed about $97.5 \%$ of the extractable monoterpenes. In sample A, tree No. 2, which weighed about three times more, only about $89 \%$ of the monoterpenes were removed. The quantities of monoterpenes in Table 4 have been corrected for the estimated amounts that presumably were not extracted.

Pheromone production in I. paraconfusus after feeding in ponderosa pine and after exposure to vapours of myrcene and $\alpha$-pinene in the laboratory

The amounts of ipsenol and ipsdienol produced in males feeding $48 \mathrm{hr}$ in ponderosa pine logs were much greater than in males exposed a similar time to vapours of myrcene (Fig. 3). Cis-verbenol was not detected in feeding males $\left(<0.5 \times 10^{-8}\right.$ male) while comparatively large quantities were produced in males exposed to $\alpha$-pinene in the bottle (Fig. 3). Females that had fed

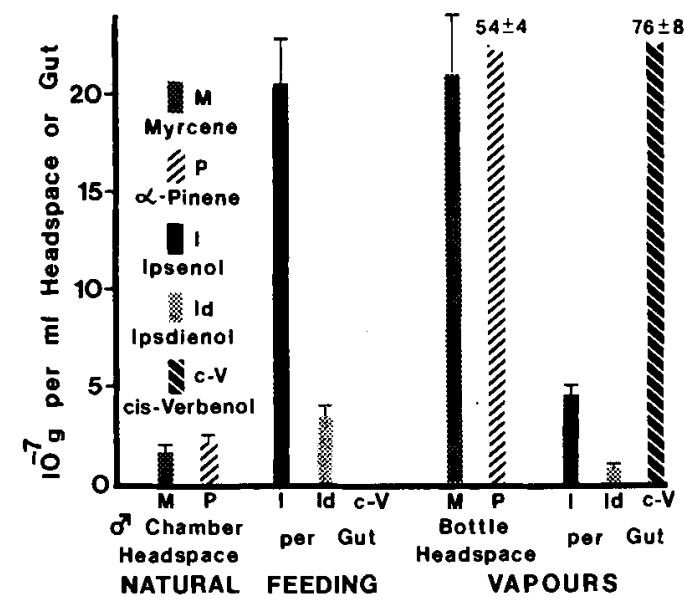

Fig. 3. Comparison of pheromone production in male $I$. paraconfusus during a $48 \mathrm{hr}$ period of feeding in ponderosa pine under natural vapour concentrations of myrcene and $\alpha$ pinene to pheromone production when exposed a similar period to higher levels of these monoterpene vapours in the laboratory. Brackets \pm S.E.M. $n=3-11$.

Table 1. Relationship between the amount of $\alpha$-pinene added to the bottle, the concentration of $\alpha$-pinene in the headspace, the subsequent production of $c i s$-verbenol and the mortality

\begin{tabular}{cccccr}
\hline Mortality & \multicolumn{2}{c}{$\begin{array}{c}\text { Cis-verbenol production } \\
\left(\times 10^{-6} \mathrm{~g}\right)\end{array}$} & $\begin{array}{c}\alpha \text {-Pinene } \\
\text { concentration } \\
\text { in headspace } \\
\left(\times 10^{-6} \mathrm{~g} / \mathrm{ml}\right)\end{array}$ & $\begin{array}{c}\alpha \text {-Pinene } \\
\text { added to } \\
\text { bottle } \\
(\mu \mathrm{l})\end{array}$ \\
$\begin{array}{c}\text { Male } \\
(\%)\end{array}$ & $\begin{array}{c}\text { Female } \\
(\%)\end{array}$ & Male & Female & & \\
\hline 0 & 0 & & & & \\
0 & 0 & $0.52 \pm 0.03$ & $0.11 \pm 0.2$ & $4.03 \pm 0.03$ & 3 \\
7 & 7 & $11.88 \pm 0.14$ & $2.04 \pm 0.53$ & $8.81 \pm 0.58$ & 30 \\
40 & 40 & $6.62 \pm 1.70$ & $3.78 \pm 0.44$ & $18.17 \pm 0.21$ & 80 \\
50 & 53 & $5.42 \pm 1.80$ & $5.33 \pm 0.79$ & $18.27 \pm 0.69$ & 160 \\
\hline
\end{tabular}

Values \pm S.E.M. $n=2-4$. 
Table 2. The comparison of the quantities of compounds produced in male $I$. paraconfusus after exposure in $\alpha$-pinene vapours (per $\mathrm{ml}$ ) to quantities produced in females and the comparisons of ratios of compounds produced in males to ratios in females

\begin{tabular}{|c|c|c|c|c|}
\hline \multirow[b]{2}{*}{ Sex } & \multicolumn{3}{|c|}{ Regression $\alpha$-pinene $(X)$ against compound $(Y)$} & \multirow[b]{2}{*}{$\begin{array}{l}\text { Difference in slopes } \\
\text { ( } P \text { value })^{*}\end{array}$} \\
\hline & Compound & $r^{2}$ & Equation $\left(\times 10^{-6} \mathrm{~g}\right)$ & \\
\hline $\begin{array}{l}0 \\
\dot{q} \\
q\end{array}$ & $\begin{array}{l}\text { cis-verbenol } \\
\text { cis-verbenol }\end{array}$ & $\begin{array}{l}0.97 \\
0.94\end{array}$ & $\begin{array}{l}Y=1.22 X-0.53 \\
Y=0.43 X-0.19\end{array}$ & $<0.001$ \\
\hline $\begin{array}{l}0 \\
\text { o } \\
+\end{array}$ & $\begin{array}{l}\text { trans-verbenol } \\
\text { trans-verbenol }\end{array}$ & $\begin{array}{l}0.99 \\
0.92\end{array}$ & $\begin{array}{l}Y=0.30 X-0.06 \\
Y=0.14 X-0.02\end{array}$ & $<0.001$ \\
\hline \multirow[t]{2}{*}{$\begin{array}{l}0 \\
0 \\
0\end{array}$} & $\begin{array}{l}\text { myrtenol } \\
\text { myrtenol }\end{array}$ & $\begin{array}{l}0.98 \\
0.89\end{array}$ & $\begin{array}{l}Y=0.32 X-0.02 \\
Y=0.22 X+0.11\end{array}$ & 0.001 \\
\hline & \multicolumn{3}{|c|}{ Regression compound $(X)$ against compound $(Y)$} & \\
\hline Sex & & $r^{2}$ & Equation $\left(\times 10^{-6} \mathrm{~g}\right)$ & $\begin{array}{c}\text { Difference in slopes } \\
\text { ( } P \text { value) }\end{array}$ \\
\hline $\begin{array}{l}0 \\
+ \\
+\end{array}$ & $\begin{array}{l}\text { cis against trans } \dagger \\
\text { cis against trans }\end{array}$ & $\begin{array}{l}0.99 \\
0.99\end{array}$ & $\begin{array}{l}Y=4.05 X-0.29 \\
Y=3.06 X-0.13\end{array}$ & $<0.001$ \\
\hline $\begin{array}{l}2 \\
9\end{array}$ & $\begin{array}{l}\text { cis against myrtenol } \\
\text { cis against myrtenol }\end{array}$ & $\begin{array}{l}0.99 \\
0.94\end{array}$ & $\begin{array}{l}Y=3.84 X-0.44 \\
Y=1.86 X-0.33\end{array}$ & $<0.001$ \\
\hline $\begin{array}{l}0 \\
0 \\
0 \\
+\end{array}$ & $\begin{array}{l}\text { myrtenol against trans } \\
\text { myrtenol against trans }\end{array}$ & $\begin{array}{l}0.99 \\
0.96\end{array}$ & $\begin{array}{l}Y=1.05 X+0.05 \\
Y=1.56 X+0.15\end{array}$ & 0.003 \\
\hline
\end{tabular}

- $P$ values $<0.05$ indicate a significant difference between the slopes of the regression lines compared (analysis of covariance).

$\dagger$ Trans represents trans-verbenol and cis represents cis-verbenol.

Table 3. The concentration $\left(10^{-8} \mathrm{~g} / \mathrm{ml}\right)$ of the monoterpene vapours in the headspace of a male $I$. paraconfusus nuptial chamber after $48 \mathrm{hr}$ of boring in logs from four ponderosa pine trees.

\begin{tabular}{lccccc}
\hline Tree & $\alpha$-Pinene & $\beta$-Pinene & $\Delta$-3-Carene & Myrcene & Limonene \\
\hline 18 Feb. 1978 & $30.9 \pm 3.3$ & $24.6 \pm 11.2$ & $34.2 \pm 11.6$ & $20.8 \pm 2.8$ & $21.3 \pm 5.1$ \\
19 Feb. 1978 & $25.5 \pm 0.8$ & $23.1 \pm 7.3$ & $62.9 \pm 22.8$ & $16.3 \pm 6.2$ & $35.2 \pm 13.1$ \\
15 Nov. 1977 & $17.6 \pm 1.2$ & $35.2 \pm 2.5$ & $50.5 \pm 3.6$ & $22.9 \pm 2.3$ & $41.5 \pm 3.2$ \\
19 March 1976 & $7.5 \pm 1.3$ & $28.9 \pm 4.7$ & $27.6 \pm 4.8$ & $3.0 \pm 0.5$ & $7.9 \pm 1.0$ \\
\hline Average \pm S.E.M. & $20.4 \pm 5.1$ & $28.0 \pm 2.7$ & $43.8 \pm 8.0$ & $15.8 \pm 4.5$ & $26.5 \pm 7.5$ \\
\hline
\end{tabular}

Values \pm S.E.M. $n=4$.

Table 4. Quantities of the major monoterpenes in ponderosa pine phloem corrected by exponential regression to account for inefficiency in the extraction process (see text)

\begin{tabular}{|c|c|c|c|c|c|c|}
\hline Tree No. 1 & $\alpha$-Pinene & Myrcene & $\beta$-Pinene & $\Delta$-3-Carene & Limonene & Total \\
\hline $\begin{array}{l}\mu \mathrm{g} / \mathrm{g} \text { tissue* } \\
\mathrm{ng} / \mu \mathrm{l} \text { tissue } \\
\text { Tree No. } 2 \\
\text { Sample A }\end{array}$ & $\begin{array}{l}84.6 \\
75.7\end{array}$ & $\begin{array}{l}41.6 \\
37.3\end{array}$ & $\begin{array}{l}173.3 \\
155.0\end{array}$ & $\begin{array}{l}332.0 \\
297.1\end{array}$ & $\begin{array}{l}76.2 \\
68.2\end{array}$ & $\begin{array}{l}707.7 \\
533.3\end{array}$ \\
\hline $\begin{array}{l}\mu \mathrm{g} / \mathrm{g} \text { tissue } \\
\mathrm{ng} / \mu \text { lissue } \\
\text { Tree No. } 2 \\
\text { Sample B }\end{array}$ & $\begin{array}{l}63.0 \\
56.5\end{array}$ & $\begin{array}{l}42.1 \\
37.6\end{array}$ & $\begin{array}{l}67.7 \\
60.6\end{array}$ & $\begin{array}{l}320.8 \\
287.0\end{array}$ & $\begin{array}{l}163.0 \\
145.9\end{array}$ & $\begin{array}{l}656.6 \\
587.6\end{array}$ \\
\hline $\begin{array}{l}\mu \mathrm{g} / \mathrm{g} \text { tissue } \\
\mathrm{ng} / \mu \mathrm{l} \text { tissue }\end{array}$ & $\begin{array}{l}82.7 \\
74.1\end{array}$ & $\begin{array}{l}58.4 \\
52.3\end{array}$ & $\begin{array}{l}87.8 \\
78.6\end{array}$ & $\begin{array}{l}342.2 \\
306.2\end{array}$ & $\begin{array}{l}137.1 \\
122.7\end{array}$ & $\begin{array}{l}708.3 \\
633.9\end{array}$ \\
\hline \multicolumn{7}{|c|}{ Average \pm S.E.M. $n=3$} \\
\hline $\begin{array}{l}\mu \mathrm{g} / \mathrm{g} \text { tissue } \\
\mathrm{ng} / \mu \mathrm{l} \text { tissue }\end{array}$ & $\begin{array}{l}76.8 \pm 6.9 \\
68.8 \pm 6.2\end{array}$ & $\begin{array}{l}47.4 \pm 5.5 \\
42.4 \pm 5.0\end{array}$ & $\begin{array}{r}109.6 \pm 32.4 \\
98.1 \pm 28.9\end{array}$ & $\begin{array}{l}331.7 \pm 6.2 \\
296.8 \pm 5.5\end{array}$ & $\begin{array}{l}125.4 \pm 25.7 \\
112.3 \pm 23.0\end{array}$ & $\begin{array}{l}690.9 \pm 17.1 \\
584.9 \pm 29.1\end{array}$ \\
\hline
\end{tabular}

* Based on phloem density of $0.895 \mathrm{~g} / \mathrm{ml}$. 
$48 \mathrm{hr}$ in logs did not contain detectable quantities of the pheromones in their guts $\left(<0.5 \times 10^{-8} \mathrm{~g} / \mathrm{female}\right)$. The ratio of ipsenol to ipsdienol in feeding males, 5:9, was similar to the ratio produced in males when exposed to myrcene vapours, $5: 8$, (Fig. 3 ) and to that found in other studies (5:9, BYERS et al., 1979; 6:0, BYERS and WOOD, 1981).

\section{DISCUSSION}

Male I. paraconfusus were able to produce about 2.8 times more cis-verbenol than females when these beetles were exposed to a range of increasing concentrations of $(-)-\alpha$-pinene vapours. If this relationship can be extrapolated to the much lower concentrations that $I$. paraconfusus experience in the nuptial chambers during colonization, then the male may synthesize as much cis-verbenol as the three females that normally join him. It is doubtful that females can enhance the attraction created by males simply by doubling the release rate of cis-verbenol. Furthermore, the presence of females in the nuptial chamber causes the male to reduce production of ipsenol and ipsdienol (BYERs, 1981). The linear relationship between $\alpha$-pinene and subsequent production of cis-verbenol, trans-verbenol and myrtenol indicates that $\alpha$-pinene is directly converted to these compounds, but experiments with radioactive $\alpha$-pinene are necessary for unequivocal proof (HENDRY et al., 1980). The relative proportions of $\mathrm{cis}$ verbenol, trans-verbenol, and myrtenol were different in males and females, indicating that the enzymatic system which regulates the levels of these compounds is in some way qualitatively different between the sexes.

The decline in monoterpene vapour concentration in the nuptial chamber headspace during the 22-day period probably reflects a decline in the concentration of monoterpenes in the phloem/xylem tissue surrounding the nuptial chamber because of evaporation (Raoult's law). In logs of smaller diameter and limbs of trees, the concentration of $\alpha$-pinene and myrcene may become limiting for pheromone biosynthesis. This may account for the loss of attraction of male infested logs after 10-14 days in the field (VITt and GaRA, 1962; VItÉ et al., 1963; BYERS, 1981) and the decline in ipsenol and ipsdienol production in unmated feeding males beginning about six days after their introduction to logs and continuing to day 12 (BYERS, 1981). However, monoterpene concentrations in areas a few millimetres away from nuptial chambers may not become limiting during this period because BYERS (1981) found ipsenol and ipsdienol production in males after three days of feeding in 12- to 14-day-old logs $(14 \mathrm{~cm}$ dia.) in the field was similar to amounts produced by males in fresh logs. Thus, males could acquire additional precursors by enlarging their chambers, at least in logs larger than $14 \mathrm{~cm}$ dia. The relative proportions of the monoterpenes in the headspace of nuptial chambers and in the phloem are similar to ratios reported previously in xylem tissue (SMITH, 1964, 1966a; ZAVARIN and COBB, 1970). MiROV (1961) reported that the monoterpenes comprise about $15 \%$ of ponderosa pine oleoresin while ZAVARIN and COBB (1970) reported $24 \%$. However, in these reports, and in several others concerning the monoterpene composition of oleoresin, the percentage by weight of xylem consisting of oleoresin was not determined (SMITh, 1964, 1965a, 1966a; Miller et al., 1968). Therefore, the titres of monoterpenes in xylem and in phloem can not be compared.

The concentration of myrcene and $\alpha$-pinene measured in the headspace of bottles at near or actual saturation was approximately 42 and 86 times, respectively, more than the concentrations found in male nuptial chambers. In several studies, bark beetles in bottles have been exposed to myrcene, $\alpha$-pinene, and other monoterpene vapours at near saturation which may have left the impression that these concentrations simulated natural conditions in the galleries of the beetle (VITÉ et al., 1972; HugHES, 1973, 1974, 1975; RENWICK et al., 1976a, b; HUGHes and RENWICK, 1977; BYERs et al., 1979; HENDRY et al., 1980). The large difference in concentration between saturation of a single or few monoterpenes in a bottle and in a nuptial chamber can be explained by the laws of Raoult and Babo. These laws state that increases in the percentage of solutes soluble in a solvent lower the vapour pressure of the solvent proportional to the amount of dissolved solutes. Since phloem and xylem consist of a complex mixture of volatile and nonvolatile substances in solution, the amounts of monoterpene that theoretically volatilize in a nuptial chamber is almost impossible to predict. The studies of pheromone production after exposure to monoterpenes at near saturation reveal the results of biosynthesis processes which otherwise would be difficult to detect under natural-conditions. The exposure of beetles to monoterpenes also can be used to experiment with the biosynthetic systems under different physiological conditions (BYERS and WOOD, 1981; BYERS, 1981). However, experiments under such conditions do not necessarily reflect natural circumstances.

SмMTH (1965a, b, 1966a, b) has proposed a theory in which the monoterpenes of ponderosa pine may function as a mechanism of tree resistance against the attack of Dendroctonous brevicomis and other bark beetles. The monoterpenes were tested singly in the vapour phase at near saturation and found to be toxic to bark beetles. The vapours from various oleoresins, 15-24\% monoterpenes (MIROV, 1961; ZAVARIN and CoBB, 1970), at saturation also were toxic over extended periods to beetles. The concentrations of monoterpenes in a bottle containing oleoresin would be considerably higher than in nuptial chambers because of the higher concentrations of monoterpenes in oleoresin than in phloem/xylem. Bark beetles have long been known to introduce several species of bluestain fungi during colonization presumably to suppress the resin flow and water conduction of the tree (MATHRE, 1964). The growth of several species of blue-stain fungi was adversely affected by monoterpene vapours (CoBB et al., 1967, 1968) indicating another possible mechanism of host resistance. However, these theories should be reevaluated because the concentrations of monoterpenes tested were much higher than natural conditions.

Based on the relationship between myrcene vapour 
concentration and pheromone production reported by BYERS et al. (1979) and the concentrations of myrcene vapour measured in nuptial chamber headspace (Table 3), one would predict that feeding males should have produced only about $1.6 \%$ of the amount of ipsenol and ipsdienol than they actually did (Fig. 3) if they only utilized the myrcene in the air of the nuptial chamber. This discrepancy must be even greater if one considers that significant losses of the pheromones probably occurred when faecal pellets were voided during feeding (WoOD et al., 1966). Relative losses of pheromone from the gut due to diffusion over time should be comparable in both feeding and vapourexposed beetles, but absolute losses would be greater in feeding males because of larger amounts of pheromone present in their guts. Therefore, males feeding under natural conditions must obtain most of the myrcene necessary for pheromone biosynthesis from phloem/xylem tissue because the low concentration of myrcene vapour in nuptial chambers is inadequate for the production of the large amounts of ipsenol and ipsdienol.

One might expect even larger amounts of cisverbenol than ipsenol and ipsdienol in feeding males since exposure to myrcene and $\alpha$-pinene vapours in a bottle caused a much larger production of cis-verbenol than ipsenol and ipsdienol. However, the quantity of cis-verbenol assumed to be in feeding males could not be detected $\left(<0.5 \times 10^{-8} \mathrm{~g} /\right.$ beetle) even though the concentration of $\alpha$-pinene is comparable to myrcene in the phloem/xylem and in the air of the nuptial chamber. A small amount of cis-verbenol was quantified in male frass by SIL VERSTEIN et al. (1967) as about $2.5 \%$ the amount of ipsdienol, and VITÉ et al. (1972) reported hindguts of feeding $I$. paraconfusus contain small amounts of cis-verbenol. On the other hand, the relationship between $\alpha$-pinene exposure and subsequent $c i s$-verbenol production (Fig. 1) indicates that the undetectable amounts would be expected in males and females exposed to concentrations of $\alpha$-pinene found in nuptial chambers (Table 3 ) if they obtained $\alpha$-pinene for biosynthesis primarily from the air.

Male I. paraconfusus would have to eat at least $56 \mu l$ of phloem or about one half the nuptial chamber volume during $48 \mathrm{hr}$ to account for the amounts of ipsenol and ipsdienol in their guts (assuming no loss from defecation). However, males do not appear to consume this much phloem since faecal pellets make up a small portion of the frass, and even more would have to be eaten to replace pheromone lost from defecation. On the other hand, only $0.15 \mu \mathrm{l}$ of oleoresin would provide enough myrcene to make the amounts of ipsenol and ipsdienol (assuming 100\% conversion) found in feeding males. Thus, there is not enough myrcene in phloem to provide sufficient quantities for the biosynthesis of pheromones unless males feed to some extent on xylem and/or oleoresin exudations. The scoring of xylem tissue by males usually observed in nuptial chambers may function to obtain myrcene. Several droplets of oleoresin, $<0.5 \mathrm{~mm}$ dia., were usually observed in nuptial chambers after males had been removed. These droplets could be eaten along with the phloem.

Hughes and ReNwick (1977) report that $I$. paraconfusus males synthesized more ipsenol and ipsdienol from myrcene vapours and more cisverbenol from $\alpha$-pinene vapour when juvenile hormone (JH) was topically applied. They proposed that feeding stretches the gut and stimulates the brain to cause the corpora allata to release JH. This enhances the synthesis of the pheromones during exposure to precursors. However, gut stretch/feeding may not enhance pheromone synthesis because BYERS and WoOD (1981) found that males, fed a diet low in host precursors, produced the pheromones in quantities comparable to unfed males when both groups were exposed to vapours of the precursors. Furthermore, Hughes and ReNwick (1977) 'stretched' male guts by injecting air which would allow myrcene vapour to diffuse about 100,000 times faster (CHAPMAN, 1971) through the air-filled gut than in a liquid-filled gut, the normal condition. Thus, possibly promoting pheromone synthesis artificially by enhancing precursor movement to the site of pheromone synthesis within the insect.

The results of the present study indicate an alternative theory for the effects of feeding on the enhancement of pheromone production. This is that the biosynthetic system of ipsenol and ipsdienol utilizes myrcene passing through the digestive tract during feeding while diffusion of myrcene through the body appears limited possibly during transport across cell membranes (BYERS et al., 1979). The cis-verbenol biosynthetic system does not appear to utilize $\alpha$-pinene from food in the digestive tract and may be close to the trachea/tracheoles where diffusion of $\alpha$-pinene vapour may be converted to cis- and trans-verbenol and myrtenol. These compounds are more soluble in aqueous medium (haemolymph) than $\alpha$-pinene and thus may be 'excreted' readily into the hindgut. Feeding also may cause increases in $\mathrm{JH}$ titre that may enhance the synthesis of ipsenol and ipsdienol, but almost all the myrcene used for pheromone synthesis appears to enter with the food. Other evidence that indicates ipsenol and ipsdienol biosynthesis may reside in or close to the gut was reported by BYERS and Woov (1981). They found that male I. paraconfusus fed on streptomycin diet and then exposed to precursor vapours could not synthesize ipsenol and ipsdienol while cis-verbenol production appeared unaffected. This implies that symbiotic microorganisms may be involved in synthesis of the malespecific pheromones. The biosynthetic system (microorganisms?) may reside inside the gut since streptomycin is a trisaccharide and, at least in mammals, only trace amounts of that ingested are absorbed through the gut wall (FRANKLIN and SNOw, 1971).

In all species of Ips studied, the males initiate the attack, are polygamous and produce the attraction. In many species, the males utilize various ratios and concentrations of ipsenol, ipsdienol and $c i s$-verbenol in their pheromone communication system (VITt et al., 1972; SilversTeIN et al., 1966a; YounG et al., 1973). Therefore, it is probable that similar mechanisms of precursor entry, biosynthetic systems, and sites of production and accumulation will be found in other Ips species.

Acknowledgements-I would like to thank D. L. Wood, Department of Entomological Sciences, University of 
California at Berkeley for support and use of his research facilities. The work was supported in part by grants from the Rockefeller Foundation, US Forest Service, and Regional Research Project W-110, SEA/USDA (to D. L. W.). I am grateful to R. P. AKers, A. M. Liebhold, D. R. OWEN, and D. L. Wood, Department of Entomological Sciences, Univ. of Calif. at Berkeley for helpful reviews of the manuscript

\section{REFERENCES}

Brand J. M., Bracke J. W., Markovetz A. J., Wood D. L. and Browne L. E. (1975) Production of verbenol pheromone by a bacterium isolated from bark beetles. Nature 254, 136-137.

BROWNE L. E. (1972) An emergence cage and refrigerated collector for wood-boring insects and their associates. $J$. econ. Ent. 65, 1499-1501.

BYERS J. A. (1981) Effect of mating on terminating aggregation during host colonization in the bark beetle, Ips paraconfusus. J. chem. Ecol. (in press)

BYERS J. A. and WOOD D. L. (1980) Interspecific inhibition of the response of the bark beetles Dendroctonus brevicomis and Ips paraconfusus to their pheromones in the field. $J$. chem. Ecol. 6, 149-164.

BYERS J. A. and WOOD D. L. (1981) Antibiotic-induced inhibition of pheromone synthesis in a bark beetle. Science (in press).

Byers J. A., Wood D. L., Browne L. E., Fish R. H., Piatek B. and HeNDRY L. B. (1979) Relationship between a host plant compound, myrcene and pheromone production in the bark beetle Ips paraconfusus. J. Insect Physiol. 25, 477-482.

Chapman R. F. (1971) The Insects: Structure and Function. Elsevier, New York.

CobB F. W. JR, KRStiC M. and Zavarin E. (1967) Effect of pine resin and turpentine constituents on Fomes annosus and four species of Ceratocystis. (Abstr.) Phytopathology 57, 806-807.

Cobb F. W. JR, KRStić M., Zavrin E. and Barber H. W. JR (1968) Inhibitory effects of volatile oleoresin components on Fomes annosus and four Ceratocystis species. Phytopathology 58, 1327-1335.

Franklin T. J. and Snow G. A. (1971) Biochemistry of Antimicrobial Action. Academic Press, New York.

Hendry L. B., Piatek B., Browne L. E., Wood D. L., Byers J. A., FisH R. H. and Hicks R. A. (1980) In vivo conversion of a labelled host plant chemical to pheromones of the bark beetle Ips paraconfusus. Nature 284, 485.

Hughes P. R. (1973) Dendroctonus: production of pheromones and related compounds in response to host monoterprenes. Z. angew. Ent. 73, 294-312.

HUGHES P. R. (1974) Myrcene: a precursor of pheromones in Ips beetles. J. Insect Physiol 20, 1271-1275.

HUGHes P. R. (1975) Pheromones of Dendroctonus: origin of alpha-pinene oxidation products present in emergent adults. J. Insect Physiol. 21, 687-691.

Hughes P. R. and ReNwick J. A. A. (1977) Neural and hormonal control of pheromone biosynthesis in the bark beetle Ips paraconfusus. Physiol. Ent. 2, 117-123.

Mathre D. E. (1964) Pathogenicity of Ceratocystis Ips and Ceratocystis minor to Pinus ponderosa. Contr. Boyce Thompson Inst. Pl. Res. 22, 363-388.

Miller P. R., CobB F. W. JR and Zavarin E. (1968) III.
Effect of injury upon oleoresin composition, phloem carbohydrates, and phloem pH. Hilgardia 39, 135-140.

MiROv N. T. (1961) Composition of gum turpentine of pines. U.S. Dept. Agr. Tech. Bull. 1239.

Renwick J. A. A., Hughes P. R. and KRULl I. S. (1976a) Selective production of $c i s$ and trans-verbenol from $(-)$ and $(t)$ alpha-pinene by a bark beetle. Science 191, 199-201.

Renwick J. A. A., Hughes P. R., Pitman G. B. and Vite J. P. (1976b) Oxidation products of terpenes inentified from Dendroctonus and Ips bark beetles. J. Insect Physiol. 22, 725-727.

Silverstein R. M., Rodin J. O. and Wood D. L. (1966a) Sex attractants in frass produced by male Ips confusus in ponderosa pine. Science 154, 509-510.

Silverstein R. M., Rodin J. O. and Wood D. L. (1967) Methodology for isolation and identification of insect pheromones with reference to studies on California fivespined Ips. J. econ. Ent. 60, 944-949.

Silverstein R. M., Rodin J. O., WoOd D. L. and Browne L. E. (1966b) Identification of two new terpene alcohols from frass produced by Ips confusus in ponderosa pine. Tetrahedron 22, 1929-1936.

SMITH R. H. (1964) Variation in the monoterpenes of Pinus ponderosa Laws. Science 143, 1337-1338.

SMITH R. H. (1965a) Effect of monoterpene vapors on the western pine beetle. J. econ. Ent. 58, 509-510.

SMITH R. H. (1965b) A physiological difference among beetles of Dendroctonus ponderosae $(=D$. mondticolae $)$ and D. ponderosae $(=D$. jeffreyi $)$. Ann. ent. Soc. Am. 58, 440-442.

SMIT R. H.(1966a) The monoterpene composition of Pinus ponderosa xylem resin and of Dendroctonus brevicomis pitch tubes. Forest Sci. 12, 63-68.

SMITH R. H. (1966b) Resin quality as a factor in the resistance of pines to bark beetles. In Breeding Pest-Resistant Trees, pp. I89-196. Pergamon Press, New York.

SNedecor G. W. and Cochran W. G. (1967) Statistical Methods, 6th ed. Iowa State Univ. Press, Ames, Iowa.

VITE J. P., and GARA R. 1. (1962) Volatile attractants from ponderosa pine attacked by bark beetles (Coleoptera: Scolytidae). Contr. Boyce Thompson Inst. Pl. Res. 21, 251-274.

Vité J. P., BaKke A. and Renwick J. A. A. (1972) Pheromones in Ips (Coleoptera: Scolytidae): occurence and production. Can. Ent. 104, 1967-1975.

VITE J. P., GARA R. I. and KLIEFoth R. A. (1963) Collection and bioassay of a volatile fraction attractive to Ips confusus (LeC.) (Coleoptera: Scolytidae). Contr. Boyce Thompson Inst. Pl. Res. 22, 39-50.

Wood D. L., Browne L. E., Silverstein R. M. and Rodin J. O. (1966) Sex pheromones of bark beetles-I. Mass production, bioassay, source, and isolation of the sex pheromone of Ips confusus (LeC.). J. Insect Physiol. 12, 523-536.

Wood D. L., Browne L. E., Bedard W. D., Tilden P. E., Sil Verstein R. M. and Rodin J. O. (1968) Response of Ips confusus to synthetic sex pheromones in nature. Science 159, 1373-1374.

Young J. C., Silverstein R. M. and Birch M. C. (1973) Aggregation pheromone of the beetle Ips confusus: isolation and identification. J. Insect Physiol. 19, 2273-2277.

ZAVARIN E. and COBB F. W. JR (1970) Oleoresin variability in Pinus ponderosa. Phytochemistry 9, 2509-2515. 